Original Article

\title{
Normalized difference vegetation index for desiccation evaluation with glyphosate $+2,4$-D in magnetized spray solution
}

\author{
Índice de vegetação por diferença normalizada para avaliação de dessecação com \\ glyphosate + 2,4-D em calda magnetizada
}

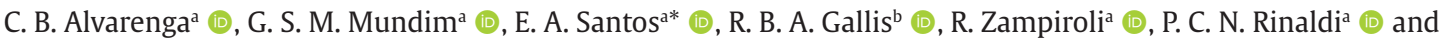 \\ J. R. Pradoc (1) \\ aUniversidade Federal de Uberlândia - UFU, Instituto de Ciências Agrárias, Monte Carmelo, MG, Brasil \\ bUniversidade Federal de Uberlândia - UFU, Instituto Geografia, Monte Carmelo, MG, Brasil \\ 'Universidade Federal de Uberlândia - UFU, Faculdade de Matemática, Monte Carmelo, MG, Brasil
}

\begin{abstract}
Water magnetization and geoprocessing are increasingly utilized tools in weed management. Our objective was to study the influence of water magnetization on herbicide efficiency and to verify whether there is a relationship between control scores and the normalized difference vegetation index (NDVI). In the laboratory experiment, water was subjected to magnetization and evaluated with respect to four characteristics. In the field experiment, plots of Brachiaria grass were subjected to treatments in a factorial scheme $(6 \times 2+1)$. Six herbicidal factors (doses of glyphosate and glyphosate $+2,4-\mathrm{D}$ ) and the magnetization or absence of magnetization of the spray solution were evaluated and compared against the control treatment (without spraying). Weed control assessments were carried out six times. Images were obtained using an embedded multispectral camera to determine the NDVI values. Data related to water characteristics were analyzed using the t test. Weed control and NDVI data were subjected to analysis of variance and are presented in regression graphs. Dispersion analysis of NDVI data was performed according to the control scores. The magnetization process decreased the $\mathrm{pH}$ of the water and increased the surface tension, but it did not influence the control scores or the NDVI. As the glyphosate dose was increased, the control scores were higher and the NDVI values were lower. Magnetized water did not affect the biological efficiency of the herbicides, and there was a strong correlation between the control scores and the NDVI values.
\end{abstract}

Keywords: control evaluation, Brachiaria decumbens, NDVI, remote sensing, application technology.

\begin{abstract}
Resumo
A magnetização da água e o geoprocessamento são ferramentas cada vez mais utilizadas no manejo de ervas daninhas. Nosso objetivo foi estudar a influência da magnetização da água na eficiência do herbicida e verificar se existe uma relação entre os escores de controle e o índice de vegetação por diferença normalizada (NDVI). No experimento de laboratório, a água foi submetida à magnetização e avaliada em relação a quatro características. No experimento de campo, parcelas de capim-braquiária foram submetidas a tratamentos em esquema fatorial $(6 \times 2+1)$. Seis fatores herbicidas (doses de glyphosate e glyphosate $+2,4-\mathrm{D})$ e a magnetização ou ausência de magnetização da calda foram avaliados e comparados com o tratamento controle (sem pulverização). Avaliações de controle de plantas daninhas foram realizadas seis vezes. As imagens foram obtidas usando uma câmera multiespectral incorporada para determinar os valores de NDVI. Os dados relacionados às características da água foram analisados por meio do teste t. $\mathrm{O}$ controle de plantas daninhas e os dados de NDVI foram submetidos à análise de variância e são apresentados em gráficos de regressão. A análise de dispersão dos dados NDVI foi realizada de acordo com os escores de controle. O processo de magnetização diminuiu o pH da água e aumentou a tensão superficial, mas não influenciou nos escores de controle ou no NDVI. Conforme a dose de glyphosate foi aumentada, os escores de controle foram maiores e os valores de NDVI foram menores. A água magnetizada não afetou a eficiência biológica dos herbicidas, e houve uma forte correlação entre os escores de controle e os valores de NDVI.
\end{abstract}

Palavras-chave: avaliação de controle, Brachiaria decumbens, NDVI, sensoriamento remoto, tecnologia de aplicação.

*e-mail: edsonsantos@ufu.br

Received: December 14, 2020 - Accepted: February 10, 2021 


\section{Introduction}

Herbicides are the most important phytosanitary products in agriculture. The main herbicides used in Brazil are glyphosate and dichlorophenoxyacetic acid (2,4-D), which are commonly applied together, since they have a synergistic effect when applied as a tank mix (Beckie, 2011). Glyphosate is registered for several operations, including post-emergent control in genetically modified crops, cleaning of areas, desiccation for no-till, and control between the lines of perennial crops. As an additive to glyphosate, 2,4-D is used in area cleaning operations and in pre-planting desiccation; in addition, it is registered for weed control in pasture areas. The main form of application of these products is liquid, with water being the main vehicle (Shaner, 2014; Harrington and Ghanizadeh, 2017).

Water has some disadvantages, such as evaporation and high surface tension. Therefore, techniques have been studied to improve the deposition of the spray solution on the target. In this sense, water magnetization can improve aspects of the application technology. The magnetic field can alter some physicochemical properties of water, and such changes modify its hardness. There are effects on $\mathrm{pH}$, the proportion of soluble solids, electrical conductivity, viscosity, and surface tension (Huo et al., 2011; Mohammadi et al., 2019). In many crops, water is subjected to a magnetization process for irrigation purposes (Silva and Dobránszki, 2014; Mohammadi et al., 2019). Once magnetized, water is also used for herbicide applications. The use of magnetized water in agriculture is also related to the efficient use of pesticides (Hozayn et al., 2013; Doklega, 2017).

Water characteristics are extremely important at the time of spraying, as water is responsible for transporting the product from the tank to the plant tissues. Magnetized water is also related to better plant development from a morphological and physiological point of view (Mohammadi et al., 2019). Thus, it is possible that magnetization of water has an effect on the mechanism by which glyphosate inhibits the enzyme 5-enolpyruvylshikimate-3-phosphate synthase (EPSPS). Magnetized water can also influence the mode of action of 2,4-D, which acts at the level of DNA and RNA (Jursík et al., 2010).

The most commonly used tools for evaluating the chemical control of weeds are those based on in loco observation of signs of herbicide injury and the attribution of control indexes, usually expressed as a percentage in relation to the control (EWRC, 1964; ALAM, 1974; Velini et al., 1995). The main signs of toxicity of glyphosate in plants are related to the change in color and structure of the aerial part. In the case of 2,4-D, the main symptoms are leaf shriveling, epinasty, wilt, and stem twisting (Jursík et al., 2010; Jursík et al., 2011).

With the advent of remote sensing techniques in agriculture, we have a new technique to assess the effectiveness of agricultural treatments; i.e., the evaluation of spectral responses to herbicide applications. For effective weed control, agricultural researchers and crop managers have sought the optimized use of herbicides, the location and identification of weeds, and the use of remote pilotable aircraft (ARPs), among many other applications (Thorp and Tian, 2004; Cassol et al., 2014; Weiss et al., 2020).
ARPs carry sensors that provide RGB (color), multispectral, or hyperspectral images. The equipment has been used worldwide for studies involving remote sensing techniques (Farooq et al., 2019). In addition, time series derived from remote detection of vegetation indices makes possible the monitoring of intra-seasonal variations in land cover (Bellón et al., 2017). Evaluating the level of weed control is possible with the use of these vegetation indices, by monitoring the variable electromagnetic reflectance of the plant according to the spectral response generated by the herbicide (Huang et al., 2018).

The objectives of this study were to i) determine the changes in the characteristics of the water after the magnetization process, and ii) compare the evaluation of chemical control of vegetation by traditional techniques with evaluations made using the remote sensing technique and NDVI.

\section{Material and Methods}

Two experiments were carried out, one in the laboratory and the other in a field area. In the laboratory, the water was characterized after the magnetization process. The experiment was carried out in a completely randomized design, with two treatments (magnetized water and non-magnetized water) and four repetitions. A magnet with the capacity to magnetize $5,000 \mathrm{~L} \mathrm{~h}^{-1}$ was added to containers with $15 \mathrm{~L}$ of tap water for $60 \mathrm{~s}$. On the side, four other $15 \mathrm{~L}$ containers, filled with tap water, were set aside as controls. A Sylocimol Rural magnetizer (Timol Group, Uberlândia, Minas Gerais, Brazil), at a power of 3860 Gauss, released magnetic flux due to the orientation of the magnets, resulting in the molecular dissociation of the water. The generated magnetic field promotes reorganization of the water molecule, making it hexagonal.

Immediately after the magnetization process, samples of the water were taken from the eight containers and evaluated for surface tension with a bench tensiometer (Kruss, K6, Hamburg, Germany), using the Du Nuoy ring method. In this method, the ring is placed on the liquid surface, and the force required to separate the ring from the surface is measured. The $\mathrm{pH}$ and electrical conductivity were measured directly in the solutions, using a pea meter and a portable conductivity meter (AKSO, AK59, São Leopoldo, Rio Grande do Sul, Brazil). The viscosity of the samples was evaluated using a micro-processed rotary viscometer (Q860M21, Diadema, São Paulo, Brazil). The device allows us to electronically measure viscosity as a measure of torsion force.

In the second experiment, we selected a field area completely occupied by Brachiaria grass (Brachiaria decumbens Stapf.) in the flowering stage (post-late), with a height of $0.6 \mathrm{~m}$. The soil is characterized as dystrophic red latosol (EMBRAPA, 2013), and the climate is tropical with dry winter (Köppen, 1936). The experiment was set up in a randomized block design in a factorial scheme $(6 \times 2+1)$, with five blocks, totaling 65 experimental units. The first factor consisted of the application of glyphosate (potassium salt) at dosages of $620,868,1,736$, and $2,604 \mathrm{~g} \mathrm{ha}^{-1}$ and glyphosate $+2,4-\mathrm{D}$ in a tank mixture at doses of $868+670$ and $1,736+670 \mathrm{~g} \mathrm{ha}^{-1}$. The second factor corresponded to the same mixtures of 
herbicides in magnetized and non-magnetized water. Additional treatment contained plots without herbicide application. The area of each plot was $5 \times 2 \mathrm{~m}$. The distance between each block was $2.0 \mathrm{~m}$ and within each block the distance between plots was $0.5 \mathrm{~m}$. The useful portion of each block was represented by the central $6.75 \mathrm{~m}^{2}$.

The herbicides were applied using a backpack sprayer, with working pressure maintained by compressed $\mathrm{CO}_{2}$. In the spray boom, four flat-spray air induction nozzles, model AD-IA 02, were installed at a working pressure of $200 \mathrm{kPa}$. The bar was positioned $0.5 \mathrm{~m}$ from the target, and $200 \mathrm{~L} \mathrm{ha}^{-1}$ of spray solution was applied. At the time of application, the average air temperature and relative humidity were $27.3{ }^{\circ} \mathrm{C}$ and $57 \%$, respectively. The wind speed was $8.3 \mathrm{~km} \mathrm{~h}^{-1}$.

At $1,5,8,12,16$, and 21 days after application (DAA), the plants were evaluated for visual symptoms of toxicity by three evaluators. Scores from 0 to 40 indicate poor control, from 41 to 60 regular control, from 61 to 70 sufficient control, from 71 to 80 good control, from 81 to 90 very good control, and from 91 to 100 excellent control. Evaluations were always performed at the same time (ALAM, 1974).

On the same days, flights were performed with a DJI brand ARP, Phantom 4 Pro model (RGB 20 MP camera) that carried an embedded Mapir camera (Survey $3 \mathrm{~W}$ ). The ARP flew over the area, at a height of $30 \mathrm{~m}$, between 12:00 pm and 1:00 pm (Brasília time, DF), with no clouds. A radiometric calibration target was placed on the ground to calibrate the camera.

For image processing, the program Solvi (solvi.nu) was used. An orthomosaic and soil brachiaria grass segmentation was generated with the effect of herbicides, using NDVI, according to Papadopoulos et al. (2018). To determine the NDVI, the parameters used were the reflectance in the near infrared (IVP) and reflectance in the red band (V) (Equation 1).

$$
N D V I=\frac{I V P-V}{(\mathrm{IVP}+\mathrm{V})}
$$

The data related to the characteristics of the water after the magnetization process were compared using the $t$ test. The assumptions of homogeneity of variances and the normality of the residuals were tested using the Oneill-Mathews and Shapiro-Wilk tests, respectively. Afterwards, the control scores (\%) and NDVI were subjected to analysis of variance, and linear regression graphs were made according to the time. The relationship between control scores and NDVI was determined by linear regression and Pearson's correlation coefficient. For the analyses we used R software (R Core Team, 2019).

\section{Results}

The magnetization process promoted changes in the physicochemical properties of the water by reducing the $\mathrm{pH}$ values and increasing the surface tension of the water (Table 1).

There was no effect of the water magnetization process on the plant control scores. On the other hand, the increase in the dose of glyphosate and the addition of 2,4-D influenced the control efficacy. The treatment corresponding to a dose of $2,604 \mathrm{~g} \mathrm{ha}^{-1}$ glyphosate, at 15 days after spraying, provided more than $80 \%$ control. In the plots treated with $1,736 \mathrm{~g} \mathrm{ha}^{-1}$ glyphosate, 71 percent control was achieved by the end of the trial. The mixture of glyphosate (1,736 $\left.\mathrm{g} \mathrm{ha}^{-1}\right)$ with 2,4-D provided sufficient control (greater than $60 \%$ ) only at 21 days. The treatments consisting of the $620 \mathrm{~g} \mathrm{ha}^{-1}$ dose of glyphosate and the mixture with $2,4-\mathrm{D}\left(868+670 \mathrm{~g} \mathrm{ha}^{-1}\right)$ did not provide satisfactory control results (Figure 1 ).

The flights, image capture, and image processing provided the formation of the orthomosaic most representative of the experiment. NDVI values ranged between -0.21 and -0.44 and showed quadratic polynomial behavior in the plots treated with the herbicides. The analysis of the individualized plots (Figure 2) and photographs allowed easy and accurate determination of the NDVI values. In the plots without herbicides, there was no variation in the NDVI values (average value of -0.17). The increase in NDVI

Table 1. Water characterization after the magnetization process.

\begin{tabular}{|c|c|c|c|c|}
\hline \multirow{2}{*}{ Water } & \multirow{2}{*}{ pH } & Conductivity & Viscosity & $\begin{array}{c}\text { Superficial } \\
\text { tension }\end{array}$ \\
\hline & & $\left(\mathrm{mS} \mathrm{cm} \mathrm{cm}^{-1}\right)$ & $(\mathrm{mPa} s)$ & $\left(\mathrm{mN} \mathrm{m}^{-1}\right)$ \\
\hline Magnetized & $6.06 \mathrm{~b}$ & $0.047 \mathrm{a}$ & $1.05 \mathrm{a}$ & $63.4 \mathrm{a}$ \\
\hline Natural & $6.24 \mathrm{a}$ & $0.048 \mathrm{a}$ & $1.11 \mathrm{a}$ & $51.9 \mathrm{~b}$ \\
\hline CV (\%) & 1.62 & 2.89 & 3.36 & 4.95 \\
\hline
\end{tabular}

Means followed by different letters in the column differ from each other by the $t$ test $(\alpha<0.05)$; CV: coefficient of variation.
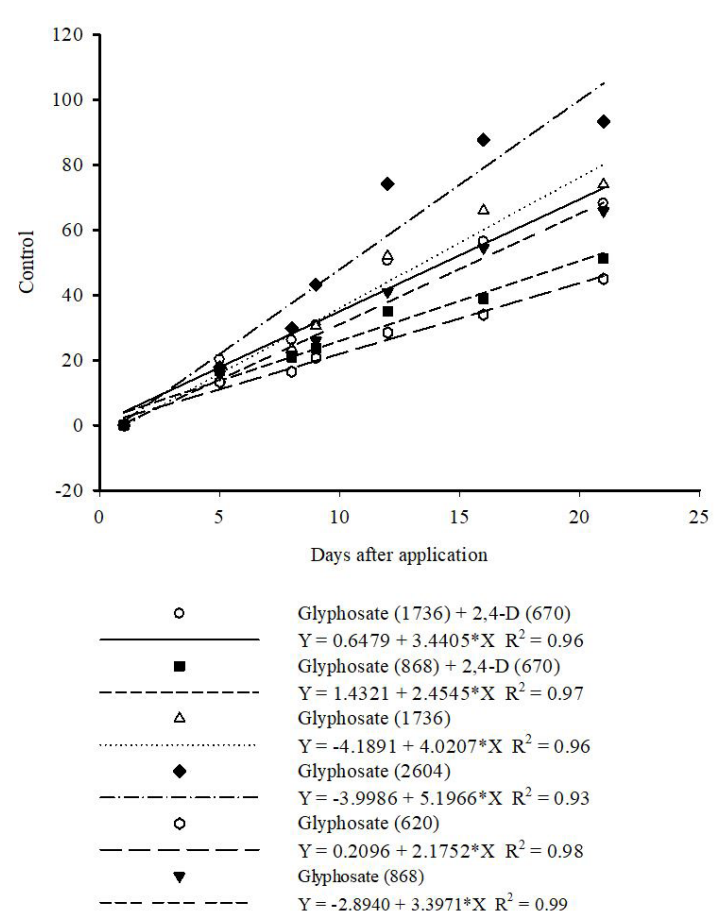

Figure 1. Trend in control scores of Brachiaria grass (Brachiaria decumbens) treated with glyphosate and glyphosate + 2,4-D. 
values was greater in the plots treated with glyphosate at a dose of 2,604 $\mathrm{g} \mathrm{ha}^{-1}$, followed by glyphosate at a dose of $1,736 \mathrm{~g} \mathrm{ha}^{-1}$. The highest NDVI values were determined in the plots that received the lowest dose of glyphosate and glyphosate + 2,4-D $\left(868+670 \mathrm{~g} \mathrm{ha}^{-1}\right)$ (Figure 3).

A significant correlation was observed between the control scores (\%), determined in the field by technicians and the NDVI values determined by analyzing the spectral responses of the Brachiaria plants. The dispersion of the data in ordered pairs is presented as a line with Pearson's correlation coefficient $₫$ equal to 0.92 (Figure 4).

\section{Discussion}

The water magnetization process promotes molecular reorganization and makes the water molecules hexagonal. Temporal changes in water characteristics promote positive responses in agriculture (Silva and Dobránszki, 2014; Hasan et al., 2020). For this reason, in some areas of Brazil, water is magnetized for use in irrigation. In many cultivated areas, the magnetizer is positioned in the general reservoir, from which water is drawn for irrigation and application of phytosanitary products. In this way, farmers also use magnetized water to apply herbicides. In the present study, it was observed that the magnetization caused changes in the $\mathrm{pH}$ and surface tension of the water.

Improved biological action of glyphosate is related to $\mathrm{pH}$ reduction in the spray solution (Cunha et al., 2017). Electrical conductivity is related to the size of the droplet and has the potential to interfere with the biological efficacy of control depending on interactions with electrical charges, formulation, and concentration of products. Viscosity is a factor that is relevant to the safety of the workers using the applicators, environmental safety, and the protection of neighboring crops. A less viscous spray solution can result in smaller drops, which have a greater propensity to be carried by the wind (Cunha et al., 2017; Assunção et al., 2019). Surface tension is the result of interactions that occur between the spray components, and high surface tension contributes to less effective spraying of herbicides (Almeida et al., 2020). In the present study, magnetization increased the surface tension of the spray solution, thereby reducing the spreading ability of the drop on the vegetable target.

Despite changes in the two water characteristics, the magnetization process had no effect on the results of biological control effectiveness. In the application, a spray volume of $200 \mathrm{~L} \mathrm{ha}^{-1}$ was used, which can be considered high in the context of applied systemic herbicides, given

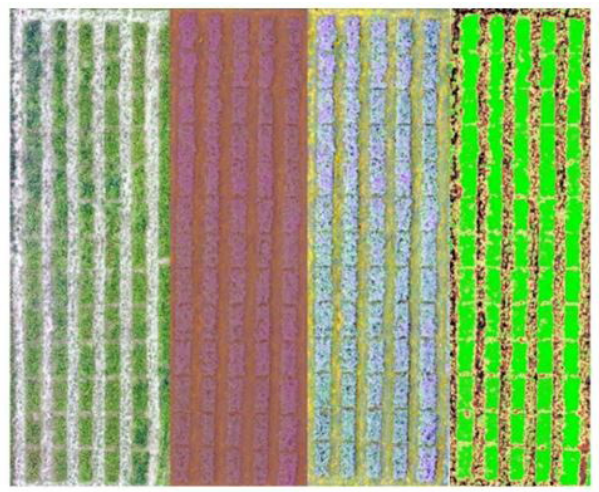

0 DAA.

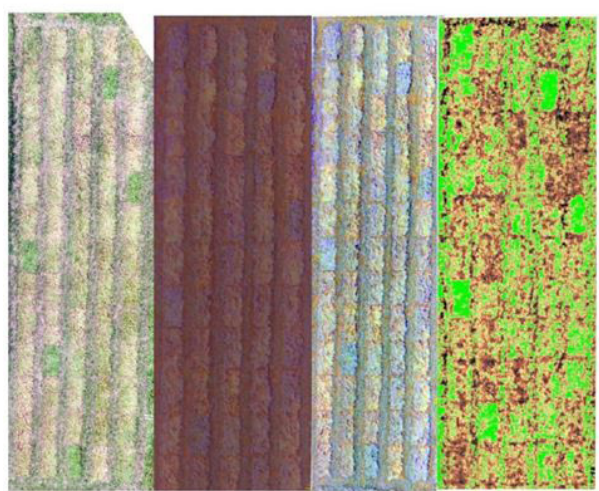

12 DAA

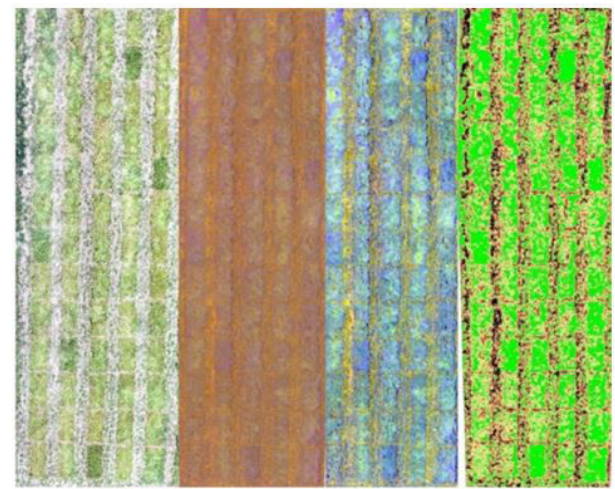

8 DAA.

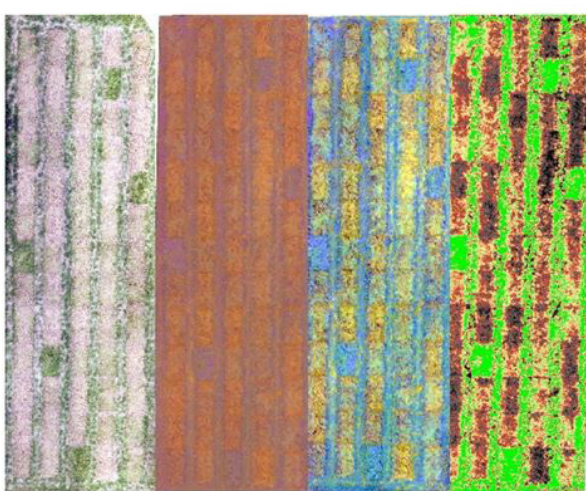

21 DAA

Figure 2. Partial view of the experimental area and change in the normalized difference vegetation index (NDVI) over four time periods (DAA: days after herbicide application). Each image presents, from left to right: color image (RGB), mapping image without radiometric calibration, image with radiometric calibration, and NDVI image. 


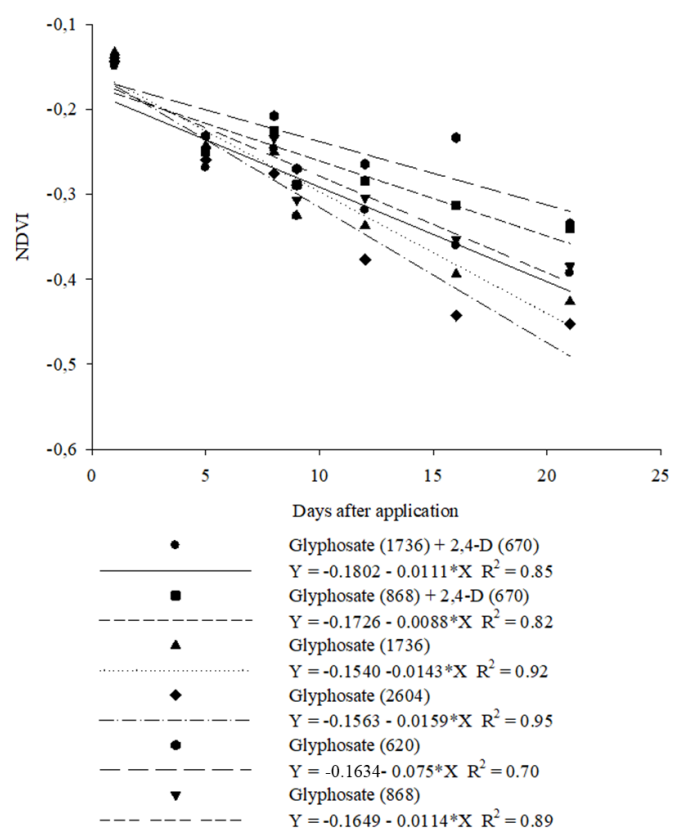

Figure 3. Changes in the NDVI in an area with Brachiaria grass plants treated with glyphosate and glyphosate $+2,4-\mathrm{D}$.

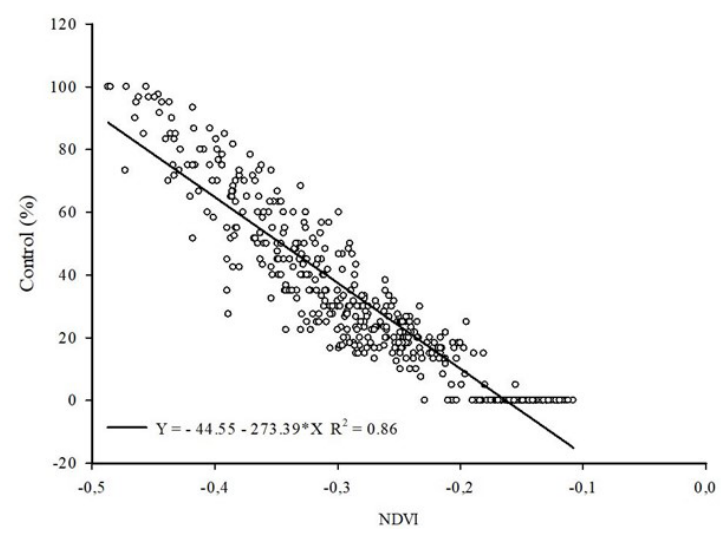

Figure 4. Dispersion of control data (\%) as a function of NDVI values generated after the application of glyphosate and glyphosate + 2,4-D in Brachiaria plants.

the high solubility in water of glyphosate and 2,4-D (Shaner, 2014). Thus, characteristics related to water magnetization did not influence the control scores, due to the large volume of water applied. Under similar conditions in a cotton crop, when the herbicide trifluralin was applied in a low volume of spray solution, with magnetized water, an improvement in weed control was observed (Al-Farttoosi et al., 2013). It is possible that the use of magnetized water for the application of other herbicides (especially those with low translocation) or in lower spray volumes, influences the weed control scores.

Glyphosate is recommended at higher dosages for perennials and for plants in the reproductive stage.
At lower doses, control is inefficient due to the ability of the target plant to metabolize the herbicide or hinder its translocation (Beckie, 2011). The herbicide 2,4-D, widely used in a mixture with glyphosate, is selective for Brachiaria species. These species exhibit differential translocation of the herbicide and protection of vascular bundles by sclerenchyma, which prevents intoxication symptoms from being observed (Shaner, 2014). Although 2,4-D is selective for Brachiaria, the herbicide can cause some disturbance that probably hinders the translocation of glyphosate in the plant. Because 2,4-D promotes the formation of tumors in the vascular bundles, when the glyphosate dose in the herbicide mixture was increased, the control improved. Brachiaria is one of the main weeds in Brazil and, in most cases, Brachiaria species occur in areas infested with eudicotyledonous plants or plants resistant to glyphosate. Therefore, it is very common to use glyphosate $+2,4-\mathrm{D}$.

NDVI is a reflectance indicator and is expressed as the ratio of the difference and the sum of the reflectance values in the near infrared and red regions. The values vary between -1 and 1 , and smaller values are related to near infrared, which indicates unhealthy vegetation (Jiang et al., 2006). In this study, it was possible to observe variation and temporal trend in NDVI as the herbicides caused symptoms of toxicity in the plants. In addition, the slope coefficients in the regression squares were higher in treatments with higher dosages of glyphosate, which indicates the sensitivity of the indicator to biological response. It is evident that the toxicity symptoms identified by the NDVI values relate to the action of glyphosate (homogeneous chlorosis followed by necrosis), since 2,4-D is selective for Brachiaria.

In the analyzed period, it was possible to observe that the trend in NDVI values did not change; that is, the symptoms of toxicity increased and remained constant. This means that the reflectance in Brachiaria plants has evolved steadily towards the near-infrared range. NDVI is highly correlated with the nutritional status of plants, especially with regard to chlorophyll content (B- Bărăscu et al., 2016). In view of the increased penetration in the plant and injuries caused by glyphosate in the aerial part, development of symptoms of toxicity was evident. Once absorbed, the glyphosate is distributed via the symplast until it reaches the phloem. Once in the phloem, the herbicide follows the flow of movement of the photo-assimilates. Therefore, the herbicide is homogeneously distributed throughout the plant and promotes a reduction in photosynthetic capacity and aromatic amino acid production (Singh et al., 2020). The symptoms increase as the herbicide is distributed in the plant.

Upon analyzing the images obtained from the ARP, we found a strong correlation between the visual assessment of injuries caused by herbicides and the NDVI values. There are a number of agricultural studies that have associated methods for determining vegetation responses with NDVI (Jiang et al., 2006; Glenn and Tabb, 2019; Shanmugapriya et al., 2019). In visual assessments of toxicity in plants, technicians must go to the field to obtain the results. Such assessments are subjective, as they depend on factors inherent to the observer, such as health, attention, environmental conditions, and vision 
(Liakos et al., 2018; Patrício and Rieder, 2018). In contrast, visual assessments made from images captured and processed with the aid of remote sensing equipment can be performed with greater accuracy and speed.

According to the model conventionally used to evaluate the effectiveness of weed control (ALAM, 1974) and the strong correlation between the two variables in the present study, vegetation NDVI values of less than -0.39 can be indicators of sufficient control of Brachiaria grass by glyphosate. In this way, the determination and interpretation of NDVI values can be used to manage glyphosate spraying. The effects of other herbicides and the sensitivity of other weeds must be studied through the spectral responses of the vegetation, but it is evident that many geoprocessing tools need to be more accessible (Hunter 3rd et al., 2020). Understanding the relationship between NDVI values and the effect of glyphosate can help crop managers accomplish several tasks: evaluate different errors in herbicide spraying, identify resistant weeds, and prevent or mitigate poisoning in non-target areas.

\section{Conclusions}

The magnetization process reduced the $\mathrm{pH}$ and increased the surface tension of the water, but did not influence the control scores or NDVI values in Brachiaria grass treated with glyphosate and glyphosate $+2,4-\mathrm{D}$.

NDVI is related to the control notes in Brachiaria grass plants treated with glyphosate and glyphosate $+2,4-\mathrm{D}$. NDVI is an accurate technique for determining herbicide control effectiveness.

\section{Acknowledgements}

To "Conselho Nacional de Desenvolvimento Científico e Tecnológico (CNPq)", “Coordenação de Aperfeiçoamento de Pessoal de Nível Superior (CAPES)" and "Fundação de Amparo à Pesquisa do Estado de Minas Gerais (FAPEMIG)" for financial support.

\section{References}

AL-FARTTOOSI, H.A.K., AL-CHALABI, F.T., JAROSZEWSKA, A. and KOWALEWSKA, R., 2013. Qualitative characters of cotton as affected by magnetized water and weed control with trifluralin. Journal of Kerbala for Agricultural Sciences, vol. 1, no. 1, pp. 20-39.

ALMEIDA, D.P., FERREIRA, M.C., SANTOS, R.T.S., GRIESANG, F., SANTOS, E.S. and TIMOSSI, P.C., 2020. Influence of glyphosate concentrations on spray solution physicochemical characteristics and drift potential. Engenharia Agrícola, vol. 40, no. 1, pp. 69-77. http://dx.doi.org/10.1590/1809-4430-eng.agric. v40n1p69-77/2020.

ASOCIACIÓN LATINOAMERICANA DE MALEZAS - ALAM, 1974. Recomendaciones sobre unificación de los sistemas de evaluación en ensayos de control de malezas. Asociación Latinoamericana de Malezas, vol. 1, no. 1, pp. 35-38.

ASSUNÇÃO, H.H.T., CAMPOS, S.F.B., SOUSA, L.A., LEMES, E.M., ZANDONADI, C.H.S. and CUNHA, J.P.A.R., 2019. Adjuvants plus phytosanitary products and the effects on the physical- chemical properties of the spray liquids. Bioscience Journal, vol. 35, no. 6, pp. 1878-1885. http://dx.doi.org/10.14393/BJv35n6a2019-46994.

BĂRĂSCU, N., DUDA, M.M. and OLTEANU, G., 2016. Study of dynamics SPAD and NDVI values of potato plants according to the differentiated fertilization. Bulletin of University of Agricultural Sciences and Veterinary Medicine Cluj-Napoca Agriculture, vol. 73, no. 1, pp. 5-14. http://dx.doi.org/10.15835/ buasvmcn-agr:12003.

BECKIE, H.J., 2011. Herbicide resistant weed management: focus on glyphosate. Pest Management Science, vol. 67, no. 9, pp. 1037-1048.

BELLÓN, B., BÉGUÉ, A., LO SEEN, D., DE ALMEIDA, C. and SIMÕES, M., 2017. A remote sensing approach for regional-scale mapping of agricultural land-use systems based on NDVI time series. Remote Sensing, vol. 9, no. 6, pp. 1-17. http://dx.doi.org/10.3390/ rs9060600.

CASSOL, A.P.V., PEREIRA FILHO, W., OLIVEIRA, M.A., DOMINGUES, A.L., CORREA, F.S. and BURIOL, G.A., 2014. First record of a bloom of the invasive species Ceratium furcoides (Levander) Langhans 1925 in Rio Grande do Sul state, Brazil. Brazilian Journal of Biology $=$ Revista Brasileira de Biologia, vol. 74, no. 2, pp. 515-517. http://dx.doi.org/10.1590/1519-6984.05413. PMid:25166340.

CUNHA, J.P.A.R., ALVES, G.S. and MARQUES, R.S., 2017. Tensão superficial, potencial hidrogeniônico e condutividade elétrica de caldas de produtos fitossanitários e adjuvantes. Ciência Agronômica, vol. 48, no. 2, pp. 261-270.

DOKLEGA, S.M.A., 2017. Impact of magnetized water irrigation, soil mineral fertilization and foliar spraying with nanomaterial on potato plants. Journal of Plant Production, vol. 8, no. 11, pp. 1113-1120. http://dx.doi.org/10.21608/jpp.2017.41123.

EMPRESA BRASILEIRA DE PESQUISA AGROPECUÁRIA - EMBRAPA, 2013. Sistema brasileiro de classificação de solos. 3. ed. Brasília: EMBRAPA, $353 \mathrm{p}$.

EUROPEAN WEED RESEARCH COUNCIL - EWRC, 1964. Report of 3rd and 4th meetings of EWRC - Committee of Methods in Weed Research. Weed Research, vol. 4, no. 1, 88 .

FAROOQ A., HU, J. and JIA, X., 2019. Analysis of spectral bands and spatial resolutions for weed classification via deep convolutional neural network. Geoscience and Remote Sensing Letters, vol. 16, no. 2, pp. 183-187.

GLENN, D.M. and TABB, A., 2019. Evaluation of five methods to measure Normalized Difference Vegetation Index (NDVI) in apple and citrus. Journal International Journal of Fruit Science, vol. 19, no. 2, pp. 191-210. http://dx.doi.org/10.1080/1553836 2.2018.1502720.

HARRINGTON, K.C. and GHANIZADEH, H., 2017. Herbicide application using wiper applicators - A review. Crop Protection (Guildford, Surrey), vol. 102, no. 5, pp. 56-62. http://dx.doi.org/10.1016/j. cropro.2017.08.009.

HASAN, M.M., ALHARBY, H.F., UDDIN, M.N., ALI, M.A., ANWAR, Y., FANG, X.W., HAKEEM, K.R., ALZAHRANI, Y. and HAJAR, A.S., 2020. Magnetized water confers drought stress tolerance in Moringa biotype via modulation of growth, gas exchange, lipid peroxidation and antioxidant activity. Polish Journal of Environmental Studies, vol. 29, no. 2, pp. 1-12. http://dx.doi. org/10.15244/pjoes/110347.

HOZAYN, M., ABD EL-MONEM, A.A., ABDELRAOUF, R.E., and ABDALLA, M.M., 2013. Do magnetized water affect water use efficiency, quality, and yield of sugar beet (Beta vulgaris L.). Journal of Agronomy, vol. 12, no. 1, pp. 1-10. 
HUANG, Y., REDDY, K.N., FLETCHER, R.S. and PENNINGTON, D., 2018. UAV low-altitude remote sensing for precision weed management. Weed Technology, vol. 32, no. 1, pp. 2-6. http:// dx.doi.org/10.1017/wet.2017.89.

HUNTER 3RD., J.E., GANNON, T.W., RICHARDSON, R.J., YELVERTON, F.H. and LEON, R.G., 2020. Integration of remote-weed mapping and an autonomous spraying unmanned aerial vehicle for site-specific weed management. Pest Management Science, vol. 76, no. 4, pp. 1386-1392. http://dx.doi.org/10.1002/ps.5651. PMid:31622004.

HUO, Z.F., ZHAO, Q. and ZHANG, Y., 2011. Experimental Study on effects of magnetization on surface tension of water. Procedia Engineering, vol. 26, no. 1, pp. 501-505.

JIANG, Z., HUETE, A.R., CHEN, J., CHEN, Y., LI, J., YAN, G. and ZHANG, X., 2006. Analysis of NDVI and scaled difference vegetation index retrievals of vegetation fraction. Remote Sensing of Environment, vol. 101, no. 3, pp. 366-378. http://dx.doi. org/10.1016/j.rse.2006.01.003.

JURSÍK, M., SOUKUP, J., HOLEC, J. and ANDR, J., 2011. Herbicide mode of actions and symptoms of plant injury by herbicides: plant growth regulator herbicides (synthetic auxins). Listy Cukrovarnické a Reparské, vol. 127, no. 3, pp. 88-92.

JURSíK, M., SOUKUP, J., VENCLOVÁ, V. and HOLEC, J., 2010. Herbicide mode of actions and symptoms of plant injury by herbicides: inhibitors of amino acid biosynthesis. Listy Cukrovarnické a Reparské, vol. 126, no. 3, pp. 250-254.

KÖPPEN, W. 1936. Das geographische System der Klimate. In:Köppen W., Geiger R. (eds) Handbuch der Klimatologie. Gebrüder Borntraeger, Berlin, pp. 1-44

LIAKOS, K.G., BUSATO, P., MSHOU, D., PEARSON, S. and BOCHTIS, D., 2018. Machine learning in agriculture: a review. Sensors (Basel), vol. 18, no. 8, pp. 2674. PMid:30110960.

MOHAMMADI, R., SASTORANI, M.T., AKBARI, M., and AHANI, H., 2019. The impacts of magnetized water treatment on different morphological and physiological factors of plant species in arid regions. Water Supply, vol. 19, no. 6, pp. 1587-1596. https://doi. org/10.2166/ws.2019.027.

PAPADOPOULOS, A.V., KATI, V., CHACHALIS, D., KOTOULAS, V. and STAMATIADIS, S., 2018. Weed mapping in cotton using ground-based sensors and GIS. Environmental Monitoring and Assessment, vol. 190, no. 10, pp. 622. http://dx.doi.org/10.1007/ s10661-018-6991-x. PMid:30269196.

PATRÍCIO, D.I. and RIEDER, R., 2018. Computer vision and artificial intelligence in precision agriculture for grain crops: a systematic review. Computers and Electronics in Agriculture, vol. 153, no. 1, pp. 69-81. http://dx.doi.org/10.1016/j.compag.2018.08.001.

R CORE TEAM, 2019. [viewed 14 December 2020]. R: a language and environment for statistical computing [online]. Vienna, Austria: R Foundation for Statistical Computing. Available from: https:// www.R-project.org/

SHANER, D.L., 2014. Herbicide handbook. 10th ed. Lawrence: Weed Science Society of America, pp. 513.

SHANMUGAPRIYA, P., RATHIKA, S., RAMESH, T. and JANAKI, P., 2019. Applications of remote sensing in agriculture - a review. International Journal of Current Microbiology and Applied Sciences, vol. 8, no. 1, pp. 2270-2283. http://dx.doi.org/10.20546/ ijcmas.2019.801.238.

SILVA, J.A.T. and DOBRÁNSZKI, J., 2014. Impact of magnetic water on plant growth. Environmental and Experimental Biology, vol. 12, no. 4, pp. 137-142.

SINGH, S., KUMAR, V., DATTA, S., WANI, A.B., DHANJAL, D.S., ROMERO, R. and SINGH, J., 2020. Glyphosate uptake, translocation, resistance emergence in crops, analytical monitoring, toxicity and degradation: a review. Environmental Chemistry Letters, vol. 18, no. 4, pp. 663-702. http://dx.doi.org/10.1007/s10311020-00969-z.

THORP, K.R. and TIAN, L.F., 2004. A review on remote sensing of weeds in agriculture. Precision Agriculture, vol. 5, no. 5, pp. 477-508. http://dx.doi.org/10.1007/s11119-004-5321-1.

VELINI, E.D., OSIPE, R. and GAZZIEIRO, D.L.P., 1995. Procedimentos para a instalação, avaliação e análise de experimentos com herbicidas. Londrina: Sociedade Brasileira da Ciência das Plantas Daninhas, pp. 42.

WEISS, M., JACOB, F. and DUVEILLER, G., 2020. Remote sensing for agricultural applications: a meta-review. Remote Sensing of Environment, vol.236, no. 2, pp.1-19. http://dx.doi.org/10.1016/j. rse.2019.111402. 